\title{
Chronic exposure to volcanic environments and cancer incidence in the Azores, Portugal
}

\author{
André Amaral ${ }^{\mathrm{a}, *}$, Victor Rodrigues ${ }^{\mathrm{b}}$, Jorge Oliveira ${ }^{\mathrm{c}}$, Carlos Pinto ${ }^{\mathrm{d}}$, Vitor Carneiro ${ }^{\mathrm{e}}$, \\ Rui Sanbento ${ }^{\mathrm{f}}$, Regina Cunha ${ }^{\mathrm{a}}$, Armindo Rodrigues ${ }^{\mathrm{a}}$ \\ a Department of Biology, University of the Azores, R. Mãe de Deus, APT 1422, 9501-855 Ponta Delgada, Portugal \\ ${ }^{b}$ Institute of Hygiene and Social Medicine, University of Coimbra, R. Larga, 3004-504 Coimbra, Portugal \\ ${ }^{\mathrm{c}}$ Health Center of Povoação, R. Mons. João Maurício Amaral Ferreira, 9650-426 Povoação, Portugal \\ ${ }^{\mathrm{d}}$ Health Center of Vila do Porto, Av. Santa Maria, 9580 Vila do Porto, Portugal \\ e Hospital do Divino Espirito Santo, Laboratory of Pathology, Grotinha-Arrifes, 9500 Ponta Delgada, Portugal \\ ${ }^{\mathrm{f}}$ Hospital do Divino Espirito Santo, Service of Oncology, Grotinha-Arrifes, 9500 Ponta Delgada, Portugal
}

Received 6 October 2005; received in revised form 14 December 2005; accepted 16 January 2006

Available online 13 March 2006

\begin{abstract}
Whether volcanic environments pose a risk in cancer incidence is unknown. We investigated this question in two populations, one from an area with active manifestations of volcanism (Furnas) and another from an area without volcanic activity since 3 million years ago (Santa Maria), both in Azores. Incidence data on cancer among the populations of Furnas and Santa Maria during 1991-2001 were obtained from medical records of local health centers. Age-standardized rates and relative risks were estimated. Overall incidence rates were higher in the volcanically active area when observing all cancers and both sexes combined. However, the non-volcanically active area presented higher rates of cancer of digestive, respiratory and intrathoracic organs, mainly in males, while the area with volcanic manifestations showed higher rates of cancer of lip, oral cavity and pharynx, in both sexes, and female breast. Relative risk estimates between both populations suggest a higher risk for cancer in some groups of organs in Furnas, especially of lip, oral cavity and pharynx cancer, and breast, that may be partially explained by the chronic exposure to environmental factors resulting from volcanic activity, such as hazardous gases and aerosols, much of them associated to trace metals.
\end{abstract}

(C) 2006 Elsevier B.V. All rights reserved.

Keywords: Volcanism; Sulfur; Cancer; Epidemiology; Incidence; Portugal

\section{Introduction}

Volcanic eruptions can generate lethal quantities of toxic gases, but long-term exposure to low doses may

\footnotetext{
* Corresponding author. Tel.: +351296650 470; fax: +351296650 100 .

E-mail address: aamaral@notes.uac.pt (A. Amaral).
}

also pose a significant risk. During and after eruptions, volcanoes release hazardous gases and aerosols such as sulfur dioxide $\left(\mathrm{SO}_{2}\right)$, sulfuric acid $\left(\mathrm{H}_{2} \mathrm{SO}_{4}\right)$, hydrogen sulfide $\left(\mathrm{H}_{2} \mathrm{~S}\right)$, hydrogen chloride $(\mathrm{HCl})$, hydrogen fluoride (HF), carbon dioxide $\left(\mathrm{CO}_{2}\right)$ and the radioactive gas radon (Rn), as well as arsenic (As), mercury $(\mathrm{Hg})$, aluminum ( $\mathrm{Al})$, rubidium $(\mathrm{Rb})$, lead $(\mathrm{Pb})$, magnesium $(\mathrm{Mg})$, copper $(\mathrm{Cu})$ and zinc $(\mathrm{Zn})$, among other metals (Delmelle and Stix, 2000; Durand et al., 2004). 
Acid gases and aerosols may irritate the eyes, nose and throat, and very high or repeated exposures may cause the development of several diseases. Sulfur compounds may cause oxidative stress and alterations in the tissues of the respiratory tract (Meng et al., 2003). Prolonged exposure to low concentrations of $\mathrm{SO}_{2}$ may be dangerous for people with preexisting cardiopulmonary diseases. When $\mathrm{SO}_{2}$ is released to the atmosphere, it oxidizes with $\mathrm{OH}$ radical in air to form sulfurous acid $\left(\mathrm{SO}_{3}\right)$, which then reacts with water to produce sulfuric acid particles (WilliamsJones and Rymer, 2000; Kikuchi, 2001). According to the International Agency for Research on Cancer (IARC), $\mathrm{SO}_{2}$ is not classifiable as to its carcinogenicity to humans, while $\mathrm{H}_{2} \mathrm{SO}_{4}$ is considered a carcinogenic for humans (IARC, 1992). Chronic exposure to $\mathrm{H}_{2} \mathrm{~S}$, which is considered an extremely toxic gas, at concentrations as low as $50 \mathrm{ppm}$ may cause pharyngitis and bronchitis, while concentrations over $250 \mathrm{ppm}$ may result in pulmonary edema (WilliamsJones and Rymer, 2000). A possible connection between chronic exposure to $\mathrm{H}_{2} \mathrm{~S}$, at lower doses, and noninfectious respiratory, nervous system and cardiovascular diseases is also referred by Bates et al. (2002) and Durand and Wilson (in press) in studies made in an urbanized geothermal field in New Zealand. In addition, Bates et al. (1998) suggest a possible association between this gas and cancer. Though $\mathrm{CO}_{2}$ normally dissipates when it leaves the ground, its moderately high density causes it to collect in hollows, wells and confined places where prolonged exposure to $\mathrm{CO}_{2}$ at concentrations above $10 \%$ creates a serious unconsciousness and asphyxia hazard (Williams-Jones and Rymer, 2000). Long-term exposure to Rn by inhalation has been linked to respiratory disorders, such as lung disease and lung cancer, in humans (Field et al., 2000, 2001). Some of the trace elements, such as $\mathrm{Cd}, \mathrm{Cr}, \mathrm{Pb}$ and $\mathrm{As}$, and compounds that contain them are known to be carcinogenic (Smith et al., 1992; Shukla et al., 1998; Waalkes, 2003).

According to the Direcção-Geral de Saúde (2001, $2002,2003)$, the mortality by cancer was in 1999,2000 and 2001 the second most important cause of death in Portugal, corresponding to approximately $20 \%$ of all deaths that have been registered for these years. Along with this, the risk of dying by cancer, in 1999, 2000 and 2001, in the Azores was higher than in Madeira and Portugal mainland. Baxter et al. (1999) demonstrated a probable health hazard associated with ground gas emissions in Furnas (São Miguel, Azores), and Bates et al. (1998) found a possible association involving geothermal air pollution and some types of cancer, in
Rotorua (New Zealand). Thus, the present populationbased retrospective cohort study tested the hypothesis that exposure to volcanic manifestations, such as hazardous gases and aerosols, poses a higher risk in cancer incidence. For this, differences in cancer burden between 1991 and 2001 were evaluated, using medical data from health centers, in two areas of the Azores (Portugal), one with active volcanic manifestations (Furnas) and the other without any kind of volcanic activity (Santa Maria).

\section{Materials and methods}

The Azores archipelago consists of nine islands and is located in the North Atlantic Ocean at the triple junction of Eurasian, African and North American plates. For that reason, the archipelago has a complex tectonic setting, where seismic-volcanic phenomena are common (Nunes et al., 1993; Lourenço et al., 1998). São Miguel, which is the largest island $\left(757 \mathrm{~km}^{2}\right)$, has its geology dominated by three volcanic cores that correspond to the major active volcanoes of Sete Cidades, Fogo and Furnas, linked by rift zones. Furnas is the easternmost of the three active volcanoes on the island São Miguel, where the last eruption occurred at $1630 \mathrm{AD}$ (Cole et al., 1995). In the presence of fumarolic fields and hydrothermal vents, the village of Furnas is built upon actively degassing ground inside Furnas caldera and has a population of about 1541 inhabitants (Serviço Regional de Estatística, 2003). Degassing soil in this village is responsible for elevated $\mathrm{CO}_{2}$ and $\mathrm{Rn}$ levels, especially indoors (Baxter et al., 1999). Santa Maria, which is one of the smallest islands $\left(92 \mathrm{~km}^{2}\right)$, encloses about 5578 inhabitants (Serviço Regional de Estatística, 2003) and is also rural, but, in contrast, has no volcanic activity since approximately 3 million years ago (Feraud et al., 1984) and is characterized by a much dryer climate than Furnas. Both populations are similar in diet, socioeconomic status, economy, home construction and access to medical care.

Incidence data on cancer among the resident population of Furnas (exposed) and of Santa Maria (non-exposed) during the period 1991 to 2001 were obtained from the medical records of each local health center. In the case of Furnas, the medical records were recorded by hand while in the case of Santa Maria they were in a computer database. No codification has been used by either the health centers, but in this study the ICD-10 (World Health Organization, 2005) codes were cautiously applied to the registries, according to major groups of neoplasms. The cancers considered were lip, oral cavity and pharynx (ICD-10, C00-C14), 
Table 1

Number of cancer cases in Furnas and Santa Maria between 1991 and 2001

\begin{tabular}{|c|c|c|c|c|c|c|}
\hline \multirow[t]{2}{*}{ Cancer } & \multicolumn{3}{|l|}{ Furnas } & \multicolumn{3}{|c|}{ Santa Maria } \\
\hline & Males & Females & Total & Males & Females & Total \\
\hline All cancers & 9 & 9 & 18 & 35 & 23 & 58 \\
\hline $\begin{array}{l}\text { Lip, oral } \\
\text { cavity and } \\
\text { pharynx } \\
(\mathrm{C} 00-\mathrm{C} 14)\end{array}$ & 2 & 1 & 3 & 0 & 0 & 0 \\
\hline $\begin{array}{l}\text { Digestive organs } \\
\text { (C15-C26) }\end{array}$ & 0 & 1 & 1 & 7 & 4 & 11 \\
\hline $\begin{array}{l}\text { Respiratory and } \\
\text { intrathoracic } \\
\text { organs } \\
(\mathrm{C} 30-\mathrm{C} 39)\end{array}$ & 1 & 0 & 1 & 11 & 1 & 12 \\
\hline Skin (C43-C44) & 1 & 0 & 1 & 0 & 0 & 0 \\
\hline $\begin{array}{l}\text { Mesothelial and } \\
\text { soft tissue } \\
\text { (C45-C49) }\end{array}$ & 1 & 0 & 1 & 0 & 0 & 0 \\
\hline Breast (C50) & & 4 & 4 & & 5 & 5 \\
\hline $\begin{array}{l}\text { Female genital } \\
\text { organs } \\
\quad(\mathrm{C} 51-\mathrm{C} 58)\end{array}$ & & 3 & 3 & & 5 & 5 \\
\hline $\begin{array}{l}\text { Male genital organs } \\
\quad \text { (C60-C63) }\end{array}$ & 3 & & 3 & 9 & & 9 \\
\hline $\begin{array}{l}\text { Ill-defined, } \\
\text { secondary and } \\
\text { unspecified sites } \\
(\mathrm{C} 76-\mathrm{C} 80)\end{array}$ & 0 & 0 & 0 & 5 & 6 & 11 \\
\hline $\begin{array}{l}\text { Lymphoid, } \\
\text { haematopoietic, } \\
\text { related tissue } \\
(\mathrm{C} 81-\mathrm{C} 96)\end{array}$ & 1 & 0 & 1 & 3 & 2 & 5 \\
\hline
\end{tabular}

digestive organs $(\mathrm{C} 15-\mathrm{C} 26)$, respiratory and intrathoracic organs $(\mathrm{C} 30-\mathrm{C} 39)$, skin $(\mathrm{C} 43-\mathrm{C} 44)$, mesothelial and soft tissue (C45-C49), breast (C50), female genital organs (C51-C58), male genital organs (C60-C63), ill-defined, secondary and unspecified sites (C76-C80), and lymphoid, haematopoietic and related tissue $(\mathrm{C} 81-\mathrm{C} 96)$. In both areas, there was no registration of cancer in bone and articular cartilage (C40-C41), urinary tract (C64-C68), eye, brain and other parts of central nervous system (C69-C72), and thyroid and other endocrine glands (C73-C75). Population denominators for incidence rates were estimated from censuses carried out in 1991 and 2001, using five age groups. Rates were adjusted to age and sex, and mean annual age-standardized rates (ASR) of cancer incidence were computed by means of the direct method on the basis of the European standard population. Age-standardized relative risk (RR) estimates were used as the measure of association defined as the incidence of cancer among individuals inhabiting Furnas (exposed) by the corresponding rate among individuals living in Santa Maria (non-exposed).

\section{Results}

The numbers of cancer cases and their distribution by sex found in Furnas and Santa Maria are presented in Table 1. The estimated sex-specific age-standardized incidence rates for Furnas and Santa Maria are shown in Figs. 1 and 2. The three most common cancers found in males from Furnas were in the genital organs $(30.6 \%$ of all cancer cases), in the lip, oral cavity and pharynx (26.1\%), and in the skin (15.9\%), while in males from Santa Maria the respiratory and intrathoracic organs $(42.8 \%)$, the genital organs $(33.8 \%)$ and the digestive organs $(26.8 \%)$ were the most affected. In females from Furnas, the principal cancers were breast $(55.6 \%)$, genital organs $(26.7 \%)$ and lip, oral cavity and pharynx along with digestive organs (13.9\% each), while in Santa Maria they were of ill-defined, secondary and unspecified sites (19.9\%), genital organs $(17.9 \%)$ and breast (14.7\%).

Males in Furnas presented 24\% less risk of cancer compared to those living in Santa Maria, however the risk in the former was higher for cancer of lip, oral cavity and pharynx (C00-C14), skin (C43-C44), and mesothelial and soft tissue (C45-C49) (Table 2). Females living in Furnas presented a $63 \%$ increased risk of cancer compared to those that live in Santa Maria. The main

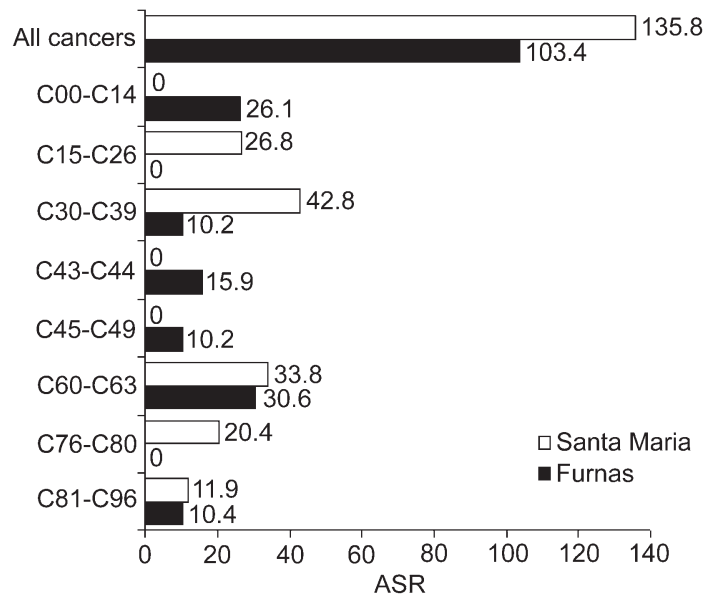

Fig. 1. Age-standardized incidence rates (per 100,000) of cancers in males of Furnas (black bars) and Santa Maria (white bars), for the period 1991-2001. C00-C14, lip, oral cavity and pharynx; C15-C26, digestive organs; $\mathrm{C} 30-\mathrm{C} 39$, respiratory and intrathoracic organs; C43-C44, skin; C45-C49, mesothelial and soft tissue; C50, breast; C51-C58, female genital organs; C60-C63, male genital organs; C76-C80, ill-defined, secondary and unspecified sites; C81-C96, lymphoid, haematopoietic and related tissue. 
cancer contributing for this was breast cancer (C50) where females from Furnas presented a $273 \%$ increased risk compared to females from Santa Maria (Table 2).

\section{Discussion}

The present paper, the first such report available for the Azores, describes and analyses the differences in cancer incidence rates in two areas of this Portuguese archipelago, one with active volcanic manifestations and the other with no type of active volcanism.

The Center of Oncology of the Azores, formed in 1979 , is responsible for producing a registry of cancer for the whole archipelago, but in 2005 this system still does not work. Consequently, a regional comprehensive cancer registration database does not exist for the Azores. The registries of cancer, as well as for other diseases, are made in each health center or hospital without regular communication between them, and many times they are recorded by hand resulting difficult to interpret when consulting is needed. Occasionally, some cases of cancer may escape from the local registries because some of the patients may be sent directly to one of the three Portuguese Institutes of Oncology, situated in Portugal mainland. A nonconclusive diagnosis or an incomplete registration may also occur. This is, however, unlikely, but if all cancers of ill-defined and unspecified sites found in Santa Maria were of a single type of cancer, the ASR found in there

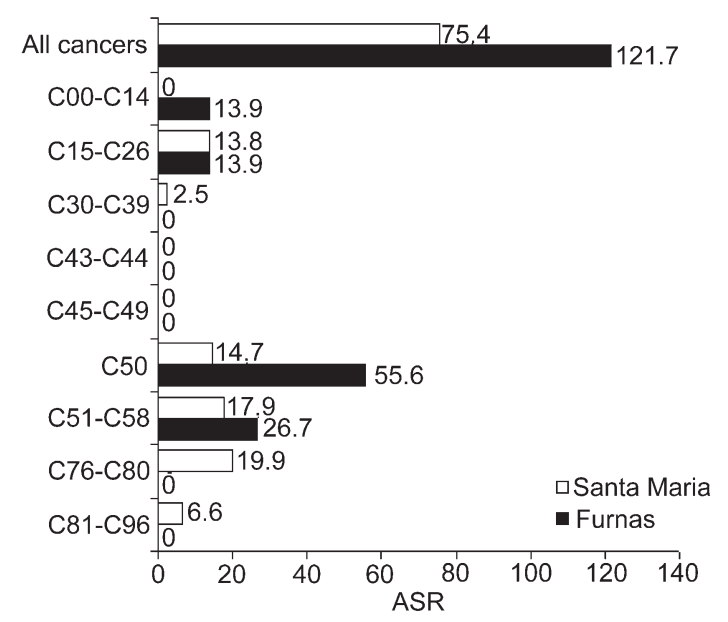

Fig. 2. Age-standardized incidence rates (per 100,000) of cancers in females of Furnas (black bars) and Santa Maria (white bars), for the period 1991-2001. C00-C14, lip, oral cavity and pharynx; C15-C26, digestive organs; $\mathrm{C} 30-\mathrm{C} 39$, respiratory and intrathoracic organs; C43-C44, skin; C45-C49, mesothelial and soft tissue; C50, breast; $\mathrm{C} 51-\mathrm{C} 58$, female genital organs; $\mathrm{C} 60-\mathrm{C} 63$, male genital organs; C76-C80, ill-defined, secondary and unspecified sites; C81-C96, lymphoid, haematopoietic and related tissue.
Table 2

Relative risk (RR) and 95\% confidence interval (CI) for cancer in active volcanic environment (Furnas), compared to reference group (Santa Maria)

\begin{tabular}{|c|c|c|c|c|}
\hline \multirow[t]{2}{*}{ Cancer } & \multicolumn{2}{|l|}{ Males } & \multicolumn{2}{|l|}{ Females } \\
\hline & $\mathrm{RR}$ & $95 \% \mathrm{CI}$ & $\mathrm{RR}$ & $95 \% \mathrm{CI}$ \\
\hline All cancers & $0.76^{*}$ & $0.58-0.98$ & $1.63 * *$ & $1.22-2.17$ \\
\hline $\begin{array}{l}\text { Lip, oral cavity } \\
\text { and pharynx } \\
(\mathrm{C} 00-\mathrm{C} 14)\end{array}$ & $\infty * *$ & - & $\infty * *$ & - \\
\hline $\begin{array}{l}\text { Digestive organs } \\
(\text { (C15-C26) }\end{array}$ & $0 * *$ & - & 1 & $0.48-2.10$ \\
\hline $\begin{array}{l}\text { Respiratory and } \\
\text { intrathoracic } \\
\text { organs } \\
\text { (C30-C39) }\end{array}$ & $0.23 * * *$ & $0.11-0.46$ & 0 & - \\
\hline Skin (C43-C44) & $\infty * *$ & - & - & - \\
\hline $\begin{array}{l}\text { Mesothelial } \\
\text { and soft } \\
\text { tissue }(\mathrm{C} 45-\mathrm{C} 49)\end{array}$ & $\infty * * *$ & - & - & - \\
\hline Breast (C50) & & & $3.73 * *$ & $2.11-6.60$ \\
\hline $\begin{array}{l}\text { Female genital } \\
\text { organs } \\
\text { (C51-C58) }\end{array}$ & & & 1.50 & $0.83-2.72$ \\
\hline $\begin{array}{l}\text { Male genital } \\
\text { organs } \\
\quad(\mathrm{C} 60-\mathrm{C} 63)\end{array}$ & 0.91 & $0.56-1.48$ & & \\
\hline $\begin{array}{l}\text { Ill-defined, } \\
\text { secondary and } \\
\text { unspecified sites } \\
\text { (C76-C80) }\end{array}$ & $0 * *$ & - & $0 * *$ & - \\
\hline $\begin{array}{l}\text { Lymphoid, } \\
\text { haematopoietic, } \\
\text { related tissue } \\
(\mathrm{C} 81-\mathrm{C} 96)\end{array}$ & 0.83 & $0.36-1.93$ & $0 * * *$ & - \\
\hline
\end{tabular}

would change the outcome of the present study. Because the populations are small, an estimated RR equal to zero or a RR tending to infinity only reflects the absence of cases in the exposed group (Furnas) or in the nonexposed group (Santa Maria), respectively.

In this study, the ASR for all cancers was higher in Furnas, where volcanic gas emissions are very common, than in Santa Maria. The cancers contributing to this difference were mainly of lip, oral cavity and pharynx $(\mathrm{C} 00-\mathrm{C} 14)$, and breast $(\mathrm{C} 50)$ that presented much higher rates in the Furnas area with 40 per 100,000 more, for each type, than Santa Maria. The rates of lip, oral cavity and pharynx cancer in Furnas were more than the double of those registered, between 1993 and 1997, for a northern city of Portugal mainland, Vila Nova de Gaia, which is very industrialized (Amado et al., 2002). For this cancer, males and 
females of Furnas presented rates twofold and fourfold higher than Vila Nova de Gaia, respectively, and when compared to 23 world areas, in 1990, and Europe, in 1995, the rates showed in Furnas are only exceeded by those of Melanesia (Parkin et al., 1999; Amado et al., 2002; Bray et al., 2002). The rates of breast cancer in Furnas were not only higher than in Santa Maria, but also higher than in Vila Nova de Gaia, and they were close to Europe and North America rates. Santa Maria on the other hand presented rates equivalent to Asia and Africa (Parkin et al., 1999; Amado et al., 2002; Bray et al., 2002). The $273 \%$ increased risk of breast cancer for females inhabiting in Furnas, when compared to those living in Santa Maria, suggests an association between this type of cancer and the volcanic environment.

Personal and environmental factors including age at onset of puberty, parity, social status and radiation exposure may influence the appearance of breast cancer (Calaf and Hei, 2000; McPherson et al., 2000). As stated by McPherson et al. (2000), radiation may double the risk of developing breast cancer and women with severe atypical benign breast diseases have a four to five times higher risk of developing this type of cancer. In addition, Calaf and Hei (2000) showed that high linear energy transfer radiation such as that emitted by radon progeny, in the presence of estrogen, induces a cascade of events symptomatic of cell alteration and carcinogenicity in human breast epithelial cells. Baxter et al. (1999) found levels of $\mathrm{Rn}$ in indoor air of houses of Furnas to be above the permissible exposure limit of $200 \mathrm{~Bq} / \mathrm{m}^{3}$ all year round with the exception of summer months. In a ground floor bedroom of one house, the level was above $8000 \mathrm{~Bq} / \mathrm{m}^{3}$. Thus, it may be hypothesized that the rates of breast cancer in Furnas may be explained partially by the presence of high levels of $\mathrm{Rn}$, which is radioactive.

In Santa Maria, the cancers with highest rates of incidence were of respiratory and intrathoracic organs (C30-C39), and of digestive organs (C15-C26). On the other hand, in Furnas, these cancers presented lower rates, especially in females. The risk of cancer in respiratory and intrathoracic organs was more than $70 \%$ less in individuals from Furnas compared to those of Santa Maria. Previous estimates (Parkin et al., 1994; Sasco et al., 2004) indicate that in European populations smoking accounts for some $90 \%$ of new cases of lung cancer in males and for 30\% in females from Southern Europe. If the majority of cancers of respiratory and intrathoracic organs refer to lung cancer, and if almost $90 \%$ of these are caused by tobacco smoking, then when making a simple theoretical exercise in which the cases of cancers of respiratory and intrathoracic organs are eliminated, the difference between Furnas and Santa
Maria in the ASR for all cancers increases and would approximately be of 45 per 100,000. Alcohol is a factor that may cause cancer of some respiratory and intrathoracic organs, but it is thought to play a much more important role in cancer of digestive organs (Parkin et al., 1994; Bray et al., 2002; Sasco et al., 2004). Thus, the higher rates of these cancers in Santa Maria, especially in males and given that females presented low rates, may probably be explained by tobacco smoking and alcohol consumption, emphasizing the well known association between these cancers and lifestyle. In agreement to this is the fact that, in terms of smoking, Furnas and Santa Maria diverge as they present $25 \%$ and $44 \%$ prevalence, respectively, and in terms of daily alcohol consumption Santa Maria also shows a higher prevalence (Peixoto, 2005). Many of the cases of cancers found today in respiratory and intrathoracic organs as well as cancers in digestive organs are probably a result of tobacco smoking and alcohol consumption engaged in the 1960s or 1970s when these habits were only permitted to males and highly censored to females. In the case of Santa Maria, a possible change of lifestyle prior, during and after those decades, may have occurred when the local airport served repeatedly as a platform between Europe and America, and several new and more appellative brands of tobacco and drinks were introduced in local grocery stores as well as in the casino created at the time.

Therefore, the high rates of cancer of lip, oral cavity and pharynx $(\mathrm{C} 00-\mathrm{C} 14)$ found in Furnas may be explained mainly by other environmental factors, such as the gas emissions rich in sulfur and aerosols containing trace metals that are ubiquitous in this area. Durand et al. (2004) found that after $20 \mathrm{~min}$ of exposure of humans to volcanic gases, the levels of $\mathrm{SO}_{2}, \mathrm{HCl}$ and As were above the short-term limits for occupational exposures set by the National Institute of Occupational Safety of Health of the United States of America, and that $\mathrm{Al}$ and $\mathrm{Hg}$ concentrations were similar to those found in industrial settings.

Although, gas chemistry and exposure in Furnas is not known as it could be, which is also the case in all few earlier studies of this type in other regions of the world, it is suggested that the much higher rates of lip, oral cavity and pharynx cancer $(\mathrm{C} 00-\mathrm{C} 14)$ and breast cancer (C50) in Furnas may be partially explained by the chronic exposure to environmental factors resulting from volcanic activity, such as hazardous gases, trace elements and radon. Bates et al. $(1998,2002)$ and Durand and Wilson (in press), who studied larger populations in New Zealand, also pointed out that continuous exposure to volcanic environments may be 
associated to an increase in cancer, and cardiovascular, nervous system and respiratory diseases. However, the question whether chronic exposure to volcanic hazardous gases and aerosols is a cause of cancer is complex, and more research on specific volcanic exposure factors, e.g. sulfur, trace elements and radon, is needed in order to know better the association between these and certain cancer types.

\section{Acknowledgements}

This study was financially supported by Centro de Investigação de Recursos Naturais (CIRN, University of the Azores) and Direcção Regional da Ciência e Tecnologia (Government of the Azores). André Amaral was supported by a $\mathrm{PhD}$ grant from Fundação para a Ciência e a Tecnologia (SFRH/BD/8186/2002).

\section{References}

Amado J, Cardoso J, Matos E, Barroso A, Calheiros JM, Vale S, et al. Portugal, Vila Nova de Gaia (1993-1997). In: Parkin DM, Whelan SL, Ferlay J, Teppo L, Thomas DB, editors. Cancer Incidence in Five Continents, vol. VIII. Lyon: IARC (IARC Scientific Publications No. 155); 2002.

Bates MN, Garrett N, Graham B, Read D. Cancer incidence, morbidity and geothermal air pollution in Roturua, New Zealand. Int $\mathrm{J}$ Epidemiol 1998;27:10-4.

Bates MN, Garrett N, Shoemack P. Investigation of health effects of hydrogen sulfide from a geothermal source. Arch Environ Health 2002;57(5):405-11.

Baxter PJ, Baubron JC, Coutinho R. Health hazards and disaster potential of ground gas emissions at Furnas volcano, São Miguel, Azores. J Volcanol Geotherm Res 1999;92:95-106.

Bray F, Sankila R, Ferlay J, Parkin DM. Estimates of cancer incidence and mortality in Europe in 1995. Eur J Cancer 2002;38:99-166.

Calaf GM, Hei TK. Establishment of a radiation- and estrogen-induced breast cancer model. Carcinogenesis 2000;21:769-76.

Cole PD, Queiroz G, Wallenstein N, Gaspar JL, Duncan AM, Guest JE. An historic subplinian/phreatomagmatic eruption: the $1630 \mathrm{AD}$ eruption of Furnas volcano, São Miguel, Azores. J Volcanol Geotherm Res 1995;69:117-35.

Delmelle P, Stix J. Volcanic gases. In: Sigurdsson H, Houghton BF, McNutt SR, Rymer H, Stix J, editors. Encyclopedia of volcanoes. San Diego: Academic Press; 2000. p. 803-16.

Direcção-Geral de Saúde, editor. Risco de morrer em Portugal, 2001. Direcção-Geral da Saúde, Lisboa, 2003.

Durand M, Wilson JG. Spatial analysis of respiratory disease on an urbanized geothermal field. Environ Res in press.

Durand M, Florkowski C, George P, Walmsley T, Weinstein P, Cole J. Elevated trace element output in urine following acute volcanic gas exposure. J Volcanol Geotherm Res 2004;134:139-48.

Feraud G, Schinke H-U, Lietz J, Gostaud J, Pritchard G, Bleil U. New $\mathrm{K}-\mathrm{Ar}$ ages, chemical analyses and magnetic data of rocks from the islands of Santa Maria (Azores). Porto Santo and Madeira (Madeira archipelago) and Gran Canaria (Canary Islands), vol. 5. Arquipélago: Ciências da Natureza; 1984. p. 213-40.

Field RW, Steck DJ, Smith BJ, Brus CP, Fisher EL, Neuberger JS, et al. Residential radon gas exposure and lung cancer. The Iowa Radon Lung Cancer Study. Am J Epidemiol 2000;151(11):1091-102.

Field RW, Steck DJ, Smith BJ, Brus CP, Fisher EF, Neuberger JS, et al. The Iowa Radon Lung Cancer Study-Phase I: residential radon gas exposure and lung cancer. Sci Total Environ 2001;272:67-72.

IARC. Occupational exposures to mists and vapours from strong inorganic acids, and other industrial chemicals. IARC Monogr Eval Carcinog Risks Hum 1992;54:41-130.

Kikuchi R. Environmental management of sulfur trioxide emission: impact of $\mathrm{SO}_{3}$ on human health. Environ Manage 2001;27:837-44.

Lourenço N, Miranda JM, Luis JF, Ribeiro A, Victor LAM, Madeira J, et al. Morpho-tectonic analysis of the Azores Volcanic Plateau from a new bathymetric compilation of the area. Mar Geophys Res 1998;20:141-56.

McPherson K, Stell CM, Dixon JM. ABC of breast diseases. Breast cancer-epidemiology, risk factors, and genetics. $\mathrm{Br}$ Med $\mathrm{J}$ 2000;321:624-8.

Meng Z, Qin G, Zhang B, Geng H, Bai Q, Bai W, et al. Oxidative damage of sulfur dioxide inhalation on lungs and hearts of mice. Environ Res 2003;93:285-92.

Nunes JC, Carvalho MR, Forjaz VH. Short note on São Miguel Island (Azores) tiltmeters. Açoreana 1993;7:633-41.

Parkin DM, Pisani P, Lopez AD, Masuyer E. At least one in seven cases of cancer is caused by smoking. Global estimates for 1985 . Int J Cancer 1994;59:494-504.

Parkin DM, Pisani P, Ferlay J. Estimates of the worldwide incidence of 25 major cancers in 1990. Int J Cancer 1999;80:827-41.

Peixoto A. Dependências e Outras Violências...Perspectiva Taxológica. DRJEFP/CRA-PSP, Ponta Delgada; 2005.

Sasco AJ, Secretan MB, Straif K. Tobacco smoking and cancer: a brief review of recent epidemiological evidence. Lung Cancer 2004;45: S3-9.

Serviço Regional de Estatística dos Açores, editor. Censos 2001. Principais resultados definitivos dos censos 1991 e 2001. SREA, Angra do Heroísmo, 2003.

Shukla VK, Prakash A, Tripathi BD, Reddy DCS, Singh S. Biliary heavy metal concentrations in carcinoma of the gall bladder: casecontrol study. Br Med J 1998;317:1288-9.

Smith AH, Hopenhayn-Rich C, Bates MN, Goeden HM, HertzPicciotto I, Duggan HM, et al. Cancer risks from arsenic in drinking water. Environ Health Perspect 1992;97:259-67.

Waalkes MP. Cadmium carcinogenesis. Mutat Res-Fundam Mol Mech Mutagen 2003;533:107-20.

Williams-Jones G, Rymer H. Hazards of volcanic gases. In: Sigurdsson H, Houghton BF, McNutt SR, Rymer H, Stix J, editors. Encyclopedia of volcanoes. San Diego: Academic Press; 2000. p. 997-1004.

World Health Organization. International statistical classification of diseases and related health problems 10th revision. 2nd ed. Geneva: WHO Press; 2005. 